DOI: $10.26418 /$ positron.v10i1.37526

\title{
Perancangan Sistem Desalinasi Air Laut Menggunakan Multi Sel Elektroda Capacitive Deionization (CDI) Berbasis Karbon Aktif Tempurung Kemiri
}

\author{
*Astuti, Zudit Efendi \\ Laboratorium Fisika Material. Jurusan Fisika, Universitas Andalas \\ Kampus Universitas Andalas, Limau Manis, Padang 25163 \\ *E-mail: tuty_phys@yahoo.com \\ (Diterima 12 November 2019; Disetujui 30 Mei 2020; Dipublikasikan 16 September 2020)
}

\begin{abstract}
Abstrak
Sistem desalinasi air laut menggunakan metode capacitive deionization (CDI) dibuat berbahan dasar karbon aktif sebagai eletroda. Penelitian ini bertujuan untuk meningkatkan dan mempercepat proses desalinasi air laut sehingga air tersebut layak untuk dikuonsumsi. Karbon aktif dibuat dari tempurung kemiri menggunakan $\mathrm{H}_{3} \mathrm{PO}_{4} 2,5 \%$ sebagai aktivator dengan suhu aktivasi $300{ }^{\circ} \mathrm{C}$, dan $700^{\circ} \mathrm{C}$. Berdasarkan data scanning electron microscope (SEM), diperoleh bahwa karbon aktif dengan suhu aktivasi $700{ }^{\circ} \mathrm{C}$ mempunyai jumlah pori yang lebih banyak dibanding karbon aktif dengan suhu aktivasi $300{ }^{\circ} \mathrm{C}$. Karbon aktif dengan suhu aktivasi $700^{\circ} \mathrm{C}$ digunakan sebagai bahan dasar pembuatan elektroda untuk sistem desalinasi. Elektroda tersebut dibuat dengan tahapan berikut, pembuatan karbon aktif dari tempurung kemiri, pembuatan sel CDI, dan perakitan multisel elektroda CDI. Sistem desalinasi disusun dengan teknik multi sel elektroda menggunakan 5 pasang sel CDI. Sel CDI dikarakterisasi dengan cyclic voltammetry (CV) untuk menentukan kapsitansi spesifik elektroda. Sedangakan hasil dari proses desalinasi dikarakterisasi menggunakan conductivitymeter untuk menentukan konduktivitas dan atomic absorpsion spectroscopy (AAS) untuk menentukan kadar natrium. Kapasitansi spesifik dari elektroda yang dihasilkan adalah $160,476 \mathrm{mF} / \mathrm{g}$. Pengurangan kadar garam pada air laut ditunjukan oleh penurunan konduktivitas dari 3850 $\mu \mathrm{S}$ menjadi $3450 \mu \mathrm{S}$. Kadar natrium menurun dari $9884,34 \mathrm{mg} / \mathrm{L}$ menjadi $2347,64 \mathrm{mg} / \mathrm{L}$, atau pengurangan kadar natrium pada proses desalinasi terjadi sebanyak 76,25 \%. Setelah proses desalinasi berlangsung selama 5 menit, kadar natrium terus menurun menjadi 2310,43 atau proses desalinasi terjadi sebanyak $76,7 \%$. Berdasarkan hasil yang diperoleh, CDI dengan multisel dapat meningkatkan proses desalinasi dan mempercepat proses desalinasi tersebut.
\end{abstract}

Kata kunci: capacitive deionization, elektroda, $\mathrm{H}_{3} \mathrm{PO}_{4}$, karbon aktif, mesopori, multi sel elektroda

\section{Latar Belakang}

Kebutuhan air bersih untuk kelangsungan hidup manusia semakin meningkat. Mengingat pentingnya air dalam kehidupan manusia, maka penyediaan air tawar perlu diupayakan secara optimal. Penyediaan air tawar dapat ditingkatkan dengan memanfaatkan air laut. Air laut tidak dapat digunakan secara langsung karena memiliki kadar garam yang tinggi yaitu sekitar $3 \%$. Senyawa pokok yang larut dalam air laut adalah garam-garaman [1]. Kadar rata-rata seluruh garam yang terdapat dalam air laut disebut salinitas. Salinitas adalah besaran yang menunjukan berapa kadar garam yang larut dalam air laut tiap kilogram yang biasanya dinyatakan dalam persen (\%) atau permil (\%).

Pengolahan air laut yang asin menjadi air tawar dikenal dengan desalinasi. Produk desalinasi biasanya berupa air dengan kandungan garam terlarut kurang dari $500 \mathrm{mg} / \mathrm{L}$ [1]. Saat ini, metode desalinasi yang sedang banyak dikembangkan adalah capacitive deionisation (CDI). CDI banyak dikembangkan karena biaya yang murah dan hemat energi karena dioperasikan pada tegangan DC rendah dibandingkan dengan metode yang lain seperti electrodialysis (ED), reverse osmosis (R0), maupun multi-stage flash evaporation (MSF) $[2,3,4,5]$. Metode CDI dilakukan dengan mengalirkan air laut melewati celah diantara elektroda yang diberi beda potensial sehingga terjadi penyerapan ion secara elektrostatis pada permukaan elektroda.

Prinsip kerja CDI yaitu terjadinya penyerapan ion-ion garam pada permukaan elektroda. Elektroda yang bermuatan negatif akan menarik ion positif (kation) seperti kalsium $\left(\mathrm{Ca}^{+}\right)$, magnesium $\left(\mathrm{Mg}^{2+}\right)$, dan natrium $\left(\mathrm{Na}^{+}\right)$, sedangkan elektroda yang bermuatan positif akan menarik ion negatif (anion) seperti klorida $\left(\mathrm{Cl}^{-}\right)$, dan nitrat 
$\left(\mathrm{NO}_{3}\right)^{-}$. Akibatnya air yang telah melewati proses desalinasi ini akan berkurang kadar garamnya.

Proses desalinasi dengan CDI akan efektif dan efisien jika bahan elektroda yang digunakan memiliki permukaan yang luas. Permukaan yang luas akan meningkatkan daya adsorbsi pada elektroda tersebut. Salah satu cara untuk meningkatkan luas permukaan adalah dengan menciptakan pori yang lebih banyak. Salah satu material berpori adalah karbon aktif. Karbon aktif memiliki luas permukaan spesifik yang luas yaitu berkisar antara (400-2200) $\mathrm{m}^{2} / \mathrm{g}$. Daya adsorbsi karbon aktif juga dipengaruhi oleh kandungan karbon yang terdapat dalam bahan. Oleh karena itu, karbon aktif dapat dibuat dari bahan yang banyak mengandung karbon, seperti kayu, batu bara, tempurung kelapa, dan tempurung kemiri $[1,6]$.

Elektroda karbon aktif dari campuran bubuk karbon aktif telah disintesis menggunakan larutan polyvinylidene fluoride (PVDF) dengan N-methyl2-pyrrolidone (NPM) sebagai ikatan polimer menggunakan metode inversi fasa basah untuk desalinasi air payau [7]. Ukuran pori elektroda yang dihasilkan adalah $(64,2-82,4) \mathrm{nm}$. Ukuran pori meningkat dengan meningkatnya kadar NPM. Besar kapasitansi listrik yang dihasilkan adalah 2,18 F/cm2 untuk $50 \%$ berat bubuk karbon aktif sampai 4,77 F/cm2 untuk $90 \%$ berat bubuk karbon aktif. Kekurangan dari penelitian ini adalah pori yang dihasilkan masih berupa makropori.

Selain itu, aplikasi kapasitor electric double layer (EDL) berbahan dasar karbon aktif dan karbon cloth juga dikembangkan untuk desalinasi air laut [8]. Plat elektroda CDI dengan bahan karbon aktif yang berasal dari tempurung kelapa dengan proses sheet casting menggunakan metode doctor blade juga telah diteliti. Kapasitansi spesifik dari elektroda yang dibuat adalah 7,8 $\mathrm{mF} / \mathrm{g}$ dengan porositas $13,4 \%$. Setelah 20 menit, kemampuan elektrosorpsi elektroda karbon berkurang karena terjadinya deadsorbsi pada sel CDI [4].

Pada penelitian sebelumnya, telah diteliti penggunaan karbon aktif dari tempurung kemiri sebagai elektroda CDI untuk desalinasi air payau. Penelitian tersebut berhasil menurunkan kadar natrium sebesar $61,58 \%$ selama 40 menit [9]. Pada penelitian ini, terlihat bahwa dibutuhkan waktu yang cukup lama dalam proses desalinasi. Penelitian selanjutnya adalah membuat sebuah sistem desalinasi yang dapat mengubah air laut menjadi air tawar menggunakan metode CDI

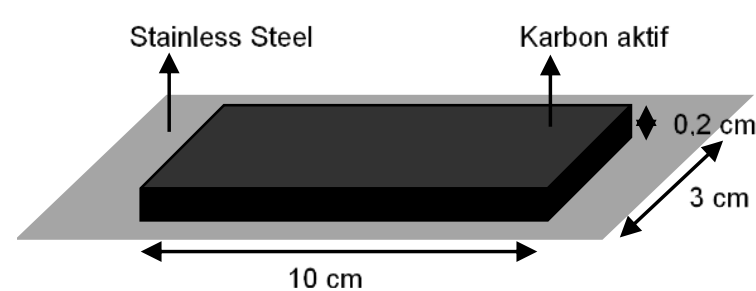

Gambar 1. Sel CDI.

dengan menggunakan karbon aktif dari tempurung kemiri. Penelitian ini difokuskan pada perancangan sistem CDI multi sel elektroda sehingga proses desalinasi dapat ditingkatkan dan berlangsung lebih cepat. Sel elektroda terdiri dari elektroda, stainless steel dan lembaran fiberglass. Penggunaan tempurung kemiri sebagai material elektroda karena mem-punyai kadar karbon yang tinggi $(51,08 \%)$, lebih tinggi jika dibandingkan dengan kayu $(46,16 \%)$, dan biji ceri $(47,52 \%)[10,11]$.

\section{Metodologi}

\section{A. Pembuatan Sel CDI}

Arang tempurung kemiri yang telah dihaluskan diayak menggunakan standard test sieve 200 mesh. Kemudian diaktivasi dalam larutan $\mathrm{H}_{3} \mathrm{PO}_{4}$ dengan konsentrasi 2,5\% selama 20 jam, selanjutnya diaktivasi menggunakan furnace dengan variasi suhu $300{ }^{\circ} \mathrm{C}$ dan $700{ }^{\circ} \mathrm{C}$ selama 90 menit, sehingga dihasilkan serbuk karbon aktif. Karbon aktif dicuci dengan aquades secara berulang sampai ph netral. Setelah diperoleh ph netral, kemudian karbon aktif dikeringkan dalam furnace pada suhu $170^{\circ} \mathrm{C}$ dan karbon aktif siap untuk diaplikasikan sebagai elektroda. Morfologi permukaan dan porositas karbon aktif dikarakterisasi menggunakann scanning electron microscopy (SEM, JEOL-JSM6510LV).

Karbon aktif dicampurkan dengan polivinil alkohol (PVA) dengan perbandingan 15:1 g. Hasil campuran karbon aktif dan PVA dilapisi pada permukaan stainless steel, kemudian dipanaskan pada suhu $50{ }^{\circ} \mathrm{C}$ selama $1 \mathrm{jam}$. Satu sel CDI terdiri atas sebuah elelektroda karbon aktif serta selembar fiber glass dengan ukuran yang sama. Betuk dan ukuran sel CDI dapat dilihat pada Gambar 1.

\section{B. Perancangan Sistem Desalinasi}

Perancangan sistem CDI untuk desalinasi air laut dilakukan dengan langkah-langkah sebagai berikut, perangkat CDI dibuat dengan menyusun 5 pasang sel elelektroda seperti Gambar 2. Kinerja elektrokimia sel CDI diuji dengan pengukuran kapasitansi dengan menggunakan alat (cyclic 


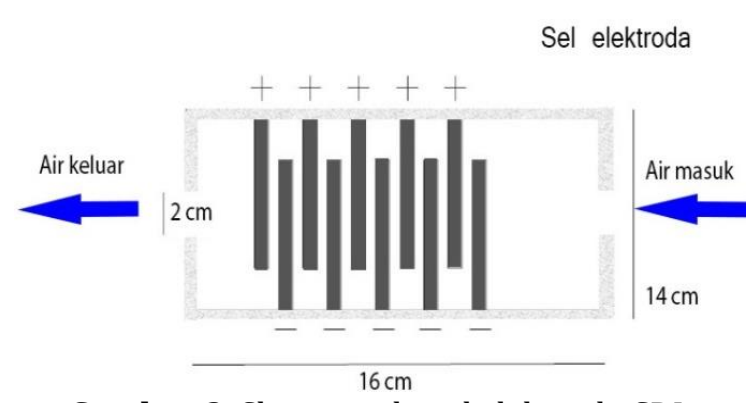

Gambar 2. Skema multi sel elektroda CDI.

voltammetry, EChem v2.1.5). CV yang digunakan bekerja dengan tiga elektroda, yaitu elektroda karbon CDI sebagai elektroda keja, logam kawat platina sebagai counter electrode dan $\mathrm{Ag} / \mathrm{AgCl}$ sebagai elektroda pembanding. Perhitungan kapasitansi dilakukan dengan menggunakan persamaan

$$
C=\frac{I t}{V},
$$

dengan $C$ adalah kapasitansi spesifik (F/g), I adalah arus puncak yang terukur (A), $t$ adalah waktu (s), dan $V$ adalah potensial (V). Pengukuran dengan $\mathrm{CV}$ menggunakan rentang potensial $-1 \mathrm{~V}$ sampai $+1 \mathrm{~V}$ dengan potensial scan rate $5 \mathrm{mV} / \mathrm{s}$.

Selanjutnya, proses desalinasi dilakukan melalui tahap-tahap sebagai berikut. Air laut dinaikan ke wadah penampungan menggunakan pompa air. Pada wadah penampungan, air laut akan disaring sehingga bahan pengotor seperti pasir tidak mempengaruhi penyerapan garam pada perangkat CDI. Setelah disaring pada wadah penampungan, air laut dialirkan ke perangkat CDI. Debit air yang masuk ke dalam perangkat CDI diatur menggunakan manual valve. Selanjutnya, ketika air laut mengalir di dalam perangkat CDI, ion-ion garam akan diserap oleh permukaan sel elektroda. Air hasil desilasi ditampung pada wadah penampungan. Kualitas penyerapan ion-ion garam oleh sel CDI pada air ini kemudian ditentukan
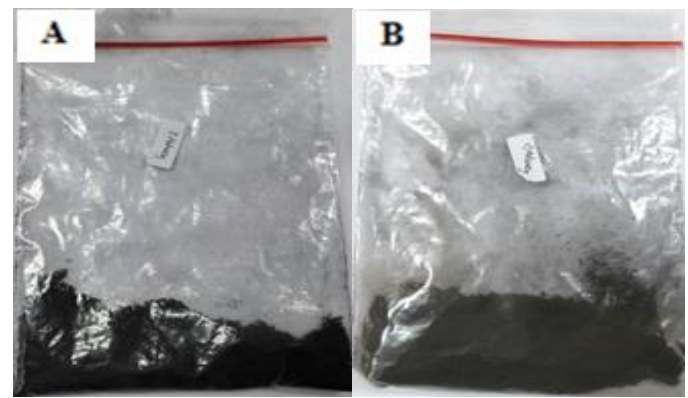

Gambar 3. Karbon aktif (A). Karbon diaktivasi pada suhu $300{ }^{\circ} \mathrm{C}$, (B). Karbon diaktivasi pada suhu $700{ }^{\circ} \mathrm{C}$. melalui pengukuran konduktivitas (conductivitymeter, CD-4303). Dalam air laut, yang berperan sebagai penghantar listrik adalah ion-ion garam seperti $\mathrm{Na}^{+}$dan $\mathrm{Cl}^{-}$, sehingga nilai konduktivitas dapat dijadikan sebagai indikator kandungan garam dalam larutan yang diuji. Selain itu, dilakukan pula karakterisasi terhadap kadar natrium dalam air hasil desalinasi menggunakan atomic absorpsion spectroscopy (AAS, Rayleight).

\section{Hasil dan Pembahasan}

\section{A. Karbon Aktif dan Karakterisasi Morfologi dan Pori}

Gambar 3 merupakan karbon aktif yang disintesis dengan suhu aktivasi $300{ }^{\circ} \mathrm{C}$ dan $700{ }^{\circ} \mathrm{C}$. Serbuk karbon aktif dikarakterisasi dengan SEM untuk melihat morfologi dan porinya seperti yang ditunjukkan pada Gambar 4.

Pada Gambar 4, terlihat munculnya pori pada semua suhu aktivasi. Pori yang muncul berbeda untuk setiap suhu aktivasi, baik bentuk maupun ukuranya. Pada suhu aktivasi $300{ }^{\circ} \mathrm{C}$ diperoleh jumlah pori yang lebih sedikit jika dibandingkan dengan suhu aktivasi $700^{\circ} \mathrm{C}$. Pada karbon aktif yang diaktivasi pada suhu $700{ }^{\circ} \mathrm{C}$, terlihat ukuran pori
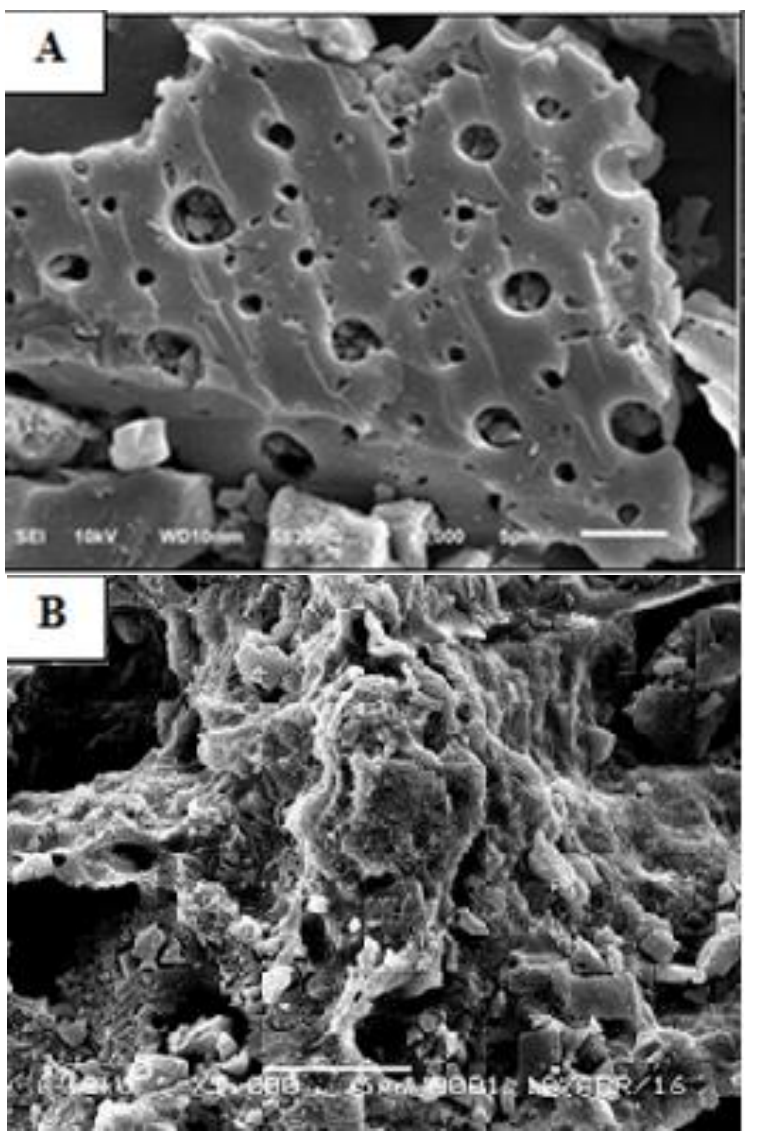

Gambar 4. SEM karbon aktif (a) diaktivasi pada suhu $300{ }^{\circ} \mathrm{C}$ dan (b) diaktivasi pada suhu $700{ }^{\circ} \mathrm{C}$. 
yang dihasilkan lebih kecil dengan jumlah pori yang lebih banyak.

Berdasarkan citra SEM, dapat dikatakan bahwa ukuran pori lebih banyak jika suhu aktivasi dinaikkan menjadi $700{ }^{\circ} \mathrm{C}$. Sama halnya dengan penelitian yang dilakukan oleh oleh Astuti dan Taspika [9], yang menunjukkan terjadinya peningkatan jumlah pori dan penurunan ukuran pori dengan kenaikan suhu aktivasi. Peningkatan jumlah pori pada suhu aktivasi $700{ }^{\circ} \mathrm{C}$ disebabkan oleh naiknya energi panas yang dapat membuka pori dan menguapkan sebagian besar aktivator. Peningkatan jumlah pori pada karbon aktif dapat meningkatkan luas permukaan aktif, sehingga dapat meningkatkan daya adsorbsi oleh karbon aktif tersebut tersebut.

\section{B. Pembuatan Elektroda Karbon dan Perhitungan Nilai Kapasitansi Spesifik}

Gambar 5. menunjukkan elektroda karbon dan bentuk pori yang dihasilkan. Pori yang dihasilkan cukup merata diseluruh permukaan elektroda, yang berfungsi untuk memperluas permukaan adsorbsi terhadap ion-ion garam yang terdapat dalam air laut. Untuk mengetahui kinerja elektroda karbon aktif sebagai sel CDI, dilakukan pengukuran kapasitansi spesifik menggunakan cyclic voltammetry $(\mathrm{CV})$.

Karakterisasi elektroda dilakukan dengan CV menggunakan scan rate $5 \mathrm{mV} / \mathrm{s}$. Proses adsorpsi dan desorbsi terjadi pada permukaan elektroda ketika elektroda diberikan potensial. Berdasarkan pengukuran, diperoleh besar arus puncak elektroda dengan suhu aktivasi karbon $300{ }^{\circ} \mathrm{C}$ adalah 1,0240 mA pada tegangan 0,9980 V. Proses elektroadsorpsi oleh elektroda berlangsung selama 300 detik. Proses elektrodesorpsi terjadi setelah elektroadsorpsi, saat arus dasar $-1,0240 \mathrm{~mA}$ pada tegangan -0,5020 V selama 600 detik. Sedangkan elektroda dengan suhu aktivasi $700 \quad{ }^{\circ} \mathrm{C}$ menghasilkan arus puncak sebesar 1,123 mA dan

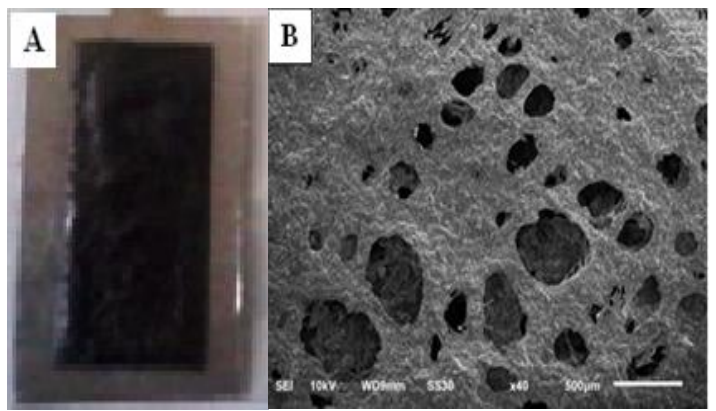

Gambar 5. (a) Elektroda karbon, (b) morfologi dan bentuk pori elektroda kabon.

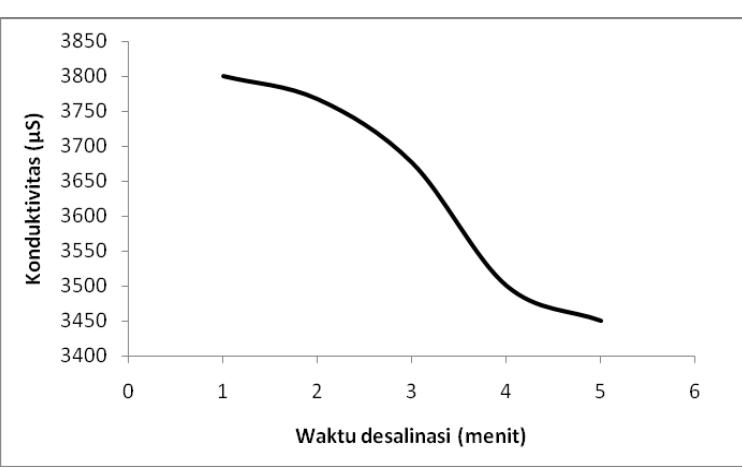

Gambar 6. Grafik konduktivitas saat poses desalinasi.

potensial maksimum sebesar 0,998 V setelah proses adsorbsi oleh elektroda berlangsung selama 300 detik. Berdasarkan data yang voltammogram siklik dan persamaan 1, diperoleh besar kapasitansi elektroda dengan suhu aktivasi karbon $300{ }^{\circ} \mathrm{C}$ adalah 307,8156 mF dan kapasitansi spesifik elektroda adalah $83,193 \mathrm{mF} / \mathrm{g}$. Sedangkan, untuk elektroda dengan suhu aktivasi $700{ }^{\circ} \mathrm{C}$ diperoleh nilai kapasitansi elektroda sebesar 337,5752 mF dan kapasitasi spesifik sebesar 160,476 mF/g. Berdasarkan data CV dan perhitungan kapasitansi, dapat disimpulkan bahwa elektroda dengan suhu aktivasi $700{ }^{\circ} \mathrm{C}$ menunjukkan kinerja elektrokimia yang lebih baik dibanding elektroda dengan suhu aktivasi $300{ }^{\circ} \mathrm{C}$.

\section{C. Kinerja Multi Sel Elektroda CDI pada Proses Desalinasi}

Setelah diperoleh data karbon aktif yang paling baik untuk proses desalinasi, lalu dilakukan proses desalinasi. Berdasarkan hasil karakterisasi SEM dan CV maka elektroda CDI yang digunakan adalah elektroda yang diaktivasi dengan suhu $700{ }^{\circ} \mathrm{C}$. Selanjutnya nilai konduktivitas air laut diukur tiap 1 menit selama 5 menit. Hasil yang didapatkan kemudian diplot dalam bentuk grafik yang ditampilkan pada Gambar 6.

Pada Gambar 6, terlihat terjadi penurunan nilai konduktivitas air laut dari $3850 \mu \mathrm{S}$ sampai $3450 \mu \mathrm{S}$ selama 5 menit. Penurunan nilai konduktivitas ini menunjukkan terjadinya penurunan ion-ion garam dalam larutan hasil desalinasi. Semakin besar kemampuan elektroda dalam menyerap ion, semakin besar pula penurunan konduktivitas yang dihasilkan. Untuk memastikan terjadinya pengurangan ion-ion garam seperti natrium dalam air hasil desalinasi maka dilakukan pengukuran kadar natrium menggunakan AAS.

Tabel 1 merupakan hasil pengukuran kadar natrium pada air setelah desalinasi. Dari data pada 
Tabel 1. Tabel kadar natrium setelah proses desalinasi.

\begin{tabular}{ccc}
\hline No & $\begin{array}{c}\text { Waktu desalinasi } \\
\text { (menit) }\end{array}$ & $\begin{array}{c}\text { Kadar natrium } \\
\text { (mg/L) }\end{array}$ \\
\hline 1 & 0 & 9884,34 \\
2 & 1 & 2347,64 \\
3 & 2 & 2320,76 \\
4 & 3 & 2319,23 \\
5 & 4 & 2317,98 \\
6 & 5 & 2310,43 \\
\hline
\end{tabular}

Tabel 1 terlihat bahwa kadar natrium dalam larutan menurun dengan bertambahnya waktu desalinasi selama 5 menit. Penurunan kadar natrium menunjukan bahwa permukaan elektroda menyerap ion natrium dari air laut ketika diberi potensial listrik. Ion tersebut teradsorbsi pada permukaan elektroda hingga proses adsorbsi mencapai kesetimbangan.

Kadar natrium menurun dari 9884,34 mg/L menjadi $2347,64 \mathrm{mg} / \mathrm{L}$ pada satu menit pertama, atau pengurangan kadar natrium pada proses desalinasi terjadi sebanyak 76,25\%. Setelah proses desalinasi berlangsung selama 5 menit, kadar natrium terus menurun menjadi 2310,43 mg/L atau sekitar 76,7\%. Kadar natrium pada Tabel 1 juga menjelaskan turunnya nilai konduktivitas air hasil desalinasi pada Gambar 6. Selain itu, penurunan kadar natrium juga diringi oleh penurunan kadar klorida selama proses desalinasi berlangsung, karna proses adsorbsi berlangsung pada permukaan elektroda positf dan elektroda negatif. Pada penelitian ini, terlihat bahwa proses desalinasi terjadi dalam waktu yang singkat dengan persentasi pengurangan kadar garam yang cukup tinggi yaitu mencapai $76,7 \%$. Penggunaan 5 pasang sel elektroda secara langsung dapat meningkatkan jumlah adsobsi ion-ion garam. Peningkatan efektivitasan sistem CDI ini harus ditunjang oleh kinerja yang baik masing-masing sel elektroda, yaitu meningkatkan luas permukaan spesifik dari elektroda karbon yang digunakan. Pada penelitian ini, digunakan elektroda yang diaktivasi pada suhu $700{ }^{\circ} \mathrm{C}$, yang mempunyai kapasitansi spesifik sebesar 160,476 mF/g. Jika dibandingkan dengan penelitian sebelumnya, Astuti dan Taspika [9] dapat menurunkan kadar garam sebesar 61,58 \% dalam waktu 40 menit. Penelitian seruapa [12] juga telah mengkonfirmasi keberhasilan proses desalinasi dengan metode CDI sebesar $71 \%$ menggunakan larutan garam dengan konsentrasi $3.000 \mathrm{mg} / \mathrm{L}$. Berdasarkan perbandingan dengan penelitian sebelumnya, dapat disimpulkan bahwa penelitian ini lebih baik dalam proses desalinasi yang dapat menurunkan kadar garam sebesar $76,25 \%$.

\section{Kesimpulan}

Berdasarkan hasil penelitian ini, dapat disimpulkan bahwa suhu aktivasi mempengaruhi daya adsobsi yang dihasilkan oleh sel elektroda CDI. Karbon aktif yang di aktivasi pada suhu $700{ }^{\circ} \mathrm{C}$ mempunyai daya adsobsi yang lebih tinggi dibandingkan dengan karbon aktif yang diaktivasi pada suhu $300{ }^{\circ} \mathrm{C}$ yaitu, berturut-turut, 160,476 $\mathrm{mF} / \mathrm{g}$ dan 83,193 mF/g. Hal ini disebabkan oleh jumlah pori yang lebih banyak, sehingga luas permukaan spesifiknya lebih besar dan kapasitansi spesifiknya juga lebih besar. Sistem desalinasi dengan multi sel elektroda ini dapat menurunkan konsentrasi natrium dalam air laut dari 9884,34 $\mathrm{mg} / \mathrm{L}$ menjadi $2347,64 \mathrm{mg} / \mathrm{L}$ pada satu menit pertama proses desalinasi, atau pengurangan kadar natrium mencapai 76,25\%. Setelah proses desalinasi berlangsung selama 5 menit, kadar natrium terus menurun menjadi 2310,43 mg/L atau sekitar 76,7\%. Pengurangan kadar garam pada air laut juga ditunjukan oleh penurunan konduktivitas dari $3850 \mu \mathrm{S}$ menjadi $3450 \mu \mathrm{S}$ selama 5 menit pertama proses desalinasi. Penurunan kadar natrium mengindikasikan bahwa karbon aktif tempurung kemiri dengan multi sel elektroda CDI ini dapat meningkatkan dan mempercepat proses desalinasi air laut.

\section{Daftar Pustaka}

[1] Zou, L, Devoloping Nano-Structured Carbon Electrodes for Capacitive Brackish Water Desalination,Desalination, Tech, pp.301-318, 2011.

[2] Wang, G., Qian, B., Dong, Q., Yang, J., Zhao, Z., dan Qiu, J, Highly Mesoporous Activated Carbon Electrode for Capacitive Deionization, Separation and Purification Technology, Vol. 103, Elsevier, pp.l 216-221, 2013

[3] Endarko, dan Fatimah, I, Fabrikasi dan Karakterisasi Elektroda untuk Sistem Capacitive Deionization (CDI) pada Proses Desalinasi Larutan $\mathrm{NaCl}$ dengan Metode Freezing-Thawing, Jurnal Teori dan Aplikasi Fisika, Vol.1, No.2, Jurusan Fisika Institut Teknologi Sepuluh November, pp. 137-144, 2013.

[4] Himmaty, I., dan Endarko, Pembuatan Elektroda dan Perancangan Sistem Capacitive Deionization untuk Mengurangi Kadar Garam 
Pada Larutan Sodium Clrorida ( $\mathrm{NaCl}$ ), Berkala Fisika, Vol.16, No.3, pp. 67-74, 2013

[5] Raman, V. K., Varigala, S. K., dan Pariyarath, P. $\mathrm{N}$, Develoment and Evaluation of an Electrode for the Capacitive Deionization Unit, Journal of Enviromental Science, Vol.8, pp 40-44, 2014.

[6] Kim, J. S., dan Choi, J. H,Fabrication and Characterization of A Carbon Electrode Coated with Cation-Exchange Polymer for The Membrane Capacitive Deionization Applications, Journal of Membrane Science, Vol.355, Elsevier, pp.85-90, 2009

[7] Lee, J. H., Bae, W. S., dan Choi, J. H,Electrode Reactions and Adsorbtion/ Desorption Performance Related to The Applied Potential in A Capacitive Deionization Proces, Desalination, Vol.258, Elsevier, pp.159-163, 2009.

[8] Fellman, B.A., Carbon-Based Electric Double Layer Capacitors for Water Desalination, Tesis, Departement of Mechanical Engineering Massachusetts Institute of Technology, Chambridge, 2010.
[9] Astuti. A, dan M. Taspika, Pembuatan Elektroda Karbon Berpori dari Tempurung Kemiri dan Perancangan Prototipe Sistem Capacitive Deionization (CDI) untuk Desalinasi Air Payau, Jurnal Pendidikan Fisika Indonesia, vol. 11, No. 1, pp. 100-107, 2015.

[10] Gonzalez, M. C. F., Serrano, G. V., Cervantest, M. R., Franco, A., dan Garcias, A. M., , Carbonization and demineralization of coals: A study by means of FT-IR spectroscopy, Matter, Vol.26, No.7, Indian Academy of Science, 2003.

[11] Lempang, M., Syafii, W., dan Pari, G, Struktur dan Komponen Arang Serta Arang Aktif Tempurung Kemiri, Jurnal Hasil Penelitian Hutan, Vol.29, No.3, Pusat Penelitian dan Pengambangan Keteknikan kahutanan dan Pengolahan Hasil Hutan, pp. 278-294, 2009.

[12] Ahmad, F, Khan, S.J, Jamal, Y., Kamran, H. Ahsan, A, Ammad, M, Khan, A., Desalination of Brakish Water Using Capasitie Deionization (CDI) Technology, Desalination and Water Treatment, Vol. 57, Taylor \& Francis, 2016. 